\title{
A Comparative Assessment of Basel II/III and Solvency II
}

\author{
Nadine Gatzert and Hannah Wesker \\ Friedrich-Alexander-University of Erlangen-Nürnberg, Lange Gasse 20, D-90403 Nürnberg, Germany. \\ E-mails: nadine.gatzert@wiso.uni-erlangen.de; hannah.wesker@wiso.uni-erlangen.de
}

In the course of creating a single European market for financial services and in the wake of two financial crises, regulatory frameworks in the financial services industry in the European Union have undergone significant change. One of the major reforms has been the transition from static rules-based systems towards principles-based regulation with the intent to better capture the risk situation of an undertaking. For insurance companies, the regulatory framework Solvency II is being finalised and is scheduled for implementation after 2013. At the same time, the regulatory regime for banking, Basel II, has been revised in response to the financial crisis; the new version is Basel III. The aim of this paper is to conduct a comprehensive and structured comparative assessment of Basel II/III and Solvency $I I$ in order to detect similarities and differences as well as the benefits and drawbacks of both regimes, which might be profitably addressed. The comparison is conducted against the background of the industries' characteristics and the objectives of regulation.

The Geneva Papers (2012) 37, 539-570. doi:10.1057/gpp.2012.3

published online 16 May 2012

Keywords: regulation; capital requirements; risk management; Solvency II; Basel II; Basel III

\section{Introduction}

Regulatory frameworks in the financial services industry in the European Union have recently undergone a significant change, as regulators move away from static rulesbased systems, in which the calculation of capital requirements is based on prespecified rules, and towards principles-based regulation, which intends to provide a better reflection of the true risk situation of an undertaking. Solvency II, the planned regulatory framework for insurance companies in the European Union, is being internationally debated because of the prominent role of the European insurance market and its ambitious goals, which constitute a major regulatory step forward. Just as Solvency II is about to be finalised, the regulatory rules for banking, Basel II, have been revised in response to perceived flaws and weaknesses that were revealed during the financial crisis of 2007/2008. These innovations and extensions of Basel II are known as Basel III. As Flamée and Windels ${ }^{1}$ state in their analysis of the ongoing cross-border and cross-sectional consolidation within the financial sector, valuable

\footnotetext{
${ }^{1}$ Flamée and Windels (2009).
} 
540

insights could be gained from a comparison of the regulatory systems for banking and insurance. In addition, Solvency II was modelled upon the Basel II three-pillar structure in order to create a level playing field for market participants. Therefore, the aim of this paper is to conduct a comprehensive but concise in-depth comparison between Basel II/III and Solvency II in light of different industry characteristics and the objectives of regulation in order to detect the similarities and differences in addition to the advantages and disadvantages of both schemes.

The literature on Basel II is extensive; thus we will refrain from a comprehensive review and concentrate on selected work. An overview of the process, the framework and implementing measures is given by the Bank for International Settlements (BIS). References herein include the framework "International Convergence of Capital Measurement and Capital Standards: A Revised Framework-Comprehensive Version"2 as well as guidelines for implementation. Concerning the (potential) impact of Basel II, two areas have been extensively discussed: the pro-cyclical effects ${ }^{3}$ and the impact on the availability and price of credit to small and medium enterprises. ${ }^{4}$ In terms of Basel $I I I$, references in the scientific literature are scarce, since these regulations have only recently been adopted. Angelini et al. ${ }^{5}$ study the impact of Basel III on long-term economic performance as well as fluctuations in economic performance, ${ }^{6}$ while Blundell-Wignall and Atkinson ${ }^{7}$ critically analyse the Basel III proposals and find some useful elements but also raise some major concerns. In addition, a summary of these new regulatory measures and the corresponding documents can be found on the homepage of the BIS.

In regard to Solvency II, Eling et al. ${ }^{8}$ and Steffen ${ }^{9}$ describe the development and main features, and Duverne and Le Douit ${ }^{10}$ discuss and compare recent developments in Solvency II and the International Financial Reporting Standards (IFRS). The impact of Solvency II on regulation in countries like Bermuda is analysed in Elderfield. ${ }^{11}$ Doff $^{12}$ tests the Solvency II regime in terms of reaching an efficient and complete market based on seven criteria developed by Cummins et al. ${ }^{13}$ and concludes that, while Solvency II meets most of the criteria, a more balanced approach between Pillar 1 and Pillars 2 and 3 is needed. This analysis is expanded by Holzmüller, ${ }^{14}$ who

${ }^{2}$ BIS (2006).

${ }^{3}$ See, for example, Ayuso et al. (2004); Heid (2007); Benford and Nier (2007).

${ }^{4}$ See, for example, Altman and Sabato (2005). Further analyses on market discipline, efficiency and an analysis of implementations costs vs. benefits are conducted in Decamps et al. (2004), Barth et al. (2004), and Herring (2005), respectively.

5 Angelini et al. (2011).

${ }^{6}$ Their estimates of the costs of higher capital requirements are used in BIS (2010d) to assess the long-term costs and benefits of stricter regulation.

${ }^{7}$ Blundell-Wignall and Atkinson (2010).

${ }^{8}$ Eling et al. (2007).

${ }^{9}$ Steffen (2008).

${ }^{10}$ Duverne and Le Douit (2009).

11 Elderfield (2009).

12 Doff (2008).

${ }^{13}$ Cummins et al. (1994).

${ }^{14}$ Holzmüller (2009). 
defines four additional criteria and evaluates the Risk-based Capital (RBC) Standard in the U.S., Solvency II and the Swiss Solvency Test (SST) using these 11 criteria and concludes that Solvency II and the SST fulfil most of the criteria, while several shortcomings for the RBC Standard are detected. An overview of the SST and its implications are presented in Eling et al. ${ }^{15}$

Further literature on the comparison of different regulatory schemes include Dacorogna and Keller, ${ }^{16}$ who compare the SST and Solvency II and point out several differences as well as analogies in implementation and conception, and Eling and Holzmüller ${ }^{17}$ who compare four regulatory schemes for the insurance industry that represent different approaches to regulation, for example, the use of static factor models or a dynamic rating-based approach. They conclude that there are major differences, especially in the applied risk measure, the potential use of internal models, and the quantification of operational and catastrophe risk. Several studies discuss and compare the U.S. RBC Standard and the Solvency II regime. Among these are Eling et al., ${ }^{18}$ Cummins and Phillips, ${ }^{19}$ Vaughan $^{20}$ as well as von Bomhard. ${ }^{21}$ Concerning a comparison between regulations for the banking and insurance sectors, Flamée and Windels ${ }^{1}$ discuss the challenges of cross-country regulation as well as advantages and disadvantages of merging the regulation of different financial sectors. Warrier $^{22}$ explains how the experiences on adopting Basel II can be helpful in the implementation of Solvency II. In addition, as groundwork for the Solvency II process, $\mathrm{CEA}^{23}$ analyses and compares eight insurance solvency regimes as well as the Basel II regime and identifies several emerging trends in regulation, including a trend towards the use of market values and the application of a total balance sheet approach.

This paper contributes to the literature by providing a comparative assessment of key framework elements of the two regulatory schemes for banking and insurance: Basel II/III and Solvency II. Such an analysis has not been conducted so far and should be of interest to different stakeholders and regulators, as Solvency II was created based on the same three-pillar structure as Basel II in order to create a level playing field for market participants and thus a comprehensive assessment of differences and similarities of both regulatory regimes might yield valuable insights and offer potential improvements for both schemes. The fact that Basel II/III and Solvency II have the same three-pillar structure is often mentioned in discussions of Solvency II. Pillar 1 states quantitative requirements concerning required capital and risk measurement, Pillar 2 involves qualitative conditions of risk management, the terms of the supervisory review process as well as the institution's own risk and solvency assessment (ORSA), and Pillar 3 is concerned with disclosure requirements.

\footnotetext{
${ }^{15}$ Eling et al. (2008).

${ }^{16}$ Dacorogna and Keller (2010).

${ }^{17}$ Eling and Holzmüller (2008).

${ }^{18}$ Eling et al. (2009).

${ }^{19}$ Cummins and Phillips (2009).

${ }^{20}$ Vaughan (2009).

21 von Bomhard (2010).

${ }^{22}$ Warrier (2007).

23 See CEA (2005).
} 
We follow the three-pillar architecture and compare key framework elements of Basel $I I / I I I$ and Solvency II to reveal major differences and similarities as well as benefits and detriments based on selected criteria. This comparison is also intended to provide a sound basis for further discussions on banking and insurance regulation.

Our results show that even though Basel II/III and Solvency II appear to be very similar at first glance, the specific contents of the three pillars differ significantly in the Basel II/III and Solvency II frameworks, partly because of the different characteristics of the industries. For example, systemic risk is more pronounced in the banking industry, which results in a stronger emphasis on the stability of the financial system in Basel II/III, while Solvency II highlights the protection of the individual policyholder. Furthermore, the balance and focus of the three pillars differ. While Pillar 1 in Solvency II uses a holistic, integrated approach of the insurance company, taking into account all quantifiable risks an insurer is exposed to and aims at a 1-year solvency probability of 99.5 per cent, Basel II/III sets limits within each of the three considered risk categories (market, credit and operational risks) and thus does not include a holistic risk perspective or a specific desired default probability. Therefore, an explicit objective of Pillar 2 of Basel II/III is to strengthen and encourage efficient and advanced risk management in order to ensure capital adequacy. Thus the banks' own risk assessment is emphasised in Basel II/III to address potential deficiencies of Pillar 1 and to obtain a holistic risk perspective. Where public disclosure requirements are concerned, both regulatory regimes comprise similar requirements. However, Solvency II also addresses the harmonisation of supervisory reporting, which Basel II/III does not.

The remainder of the paper is structured as follows: in the following section, the fundamental characteristics of the banking and insurance industry as well as the objectives of the respective regulation scheme are presented. The three pillars of Basel $I I / I I I$ and Solvency II are explained and compared in the next three sections (Pillar 1, Pillar 2, and Pillar 3, respectively), and the results of the comparison are summarised and reflected in light of the respective objectives in the penultimate section. The last section concludes.

\section{Characteristics and regulation of the banking and insurance industry}

When comparing the two regulatory regimes, the European Commission suggests that two factors are kept in mind. First, the general rules in banking and insurance should, to the extent necessary, be compatible in order to establish consistent regulation across the financial sector, that is similar products should be treated similarly in the banking and the insurance sector to avoid opportunities for regulatory arbitrage and to create a level playing field among participants in financial markets. ${ }^{24}$ However, due to the differences in economic and business activities, the two regulatory regimes will necessarily have to differ. ${ }^{25}$ Therefore, we first describe the main similarities and differences in the banking and insurance sector and, based on this, present the fundamental characteristics and aims of each regulatory scheme. In addition,

\footnotetext{
${ }^{24}$ See European Commission (2003, p. 3).

${ }^{25}$ See European Commission (2001a, p. 10).
} 
the approval process for both regimes is shortly laid out, since this process might influence the implementation of the respective regulation in national law, especially concerning the level of harmonisation achieved throughout member states. Furthermore, the main innovations of Basel III are pointed out to clarify its relationship with Basel II and to illustrate that most elements of Basel II will remain in force after the final introduction of Basel III, which justifies the use of these regulations in the following comparison.

\section{Comparison of fundamental characteristics of the banking and insurance industry}

One of the main functionalities of bank and insurance undertakings is the conduct of risk transformation. While banks mainly handle (positive) term transformation between assets and liabilities, ${ }^{26}$ that is, the horizontal transformation of (very) short term, liquid deposits to long-term credit, ${ }^{27}$ insurance companies mainly undertake vertical risk transformation on the liability side within the portfolio of insured and over time. ${ }^{27}$ Thus, liability risk is more prominent in insurance undertakings.

Considering the risk profiles of the two industries, banks are exposed mainly to financial risks, that is, to adverse changes in market conditions, which are subject to rather high correlation due to the sensitivity to common factors. ${ }^{28}$ Insurance companies, however, are exposed to both financial and non-financial risks such as weather or demographic change, which are generally idiosyncratic and non-systematic and consequently experience a lower correlation. ${ }^{29}$

Another main difference between the banking and insurance industry is the availability of funding opportunities. Funding in banking is in principle conducted rather short term through deposits and borrowing, ${ }^{30}$ while in the insurance industry funding is mainly composed of premiums paid in advance. ${ }^{31}$ The very short-term funding of banks and the resulting positive term transformation lead to high liquidity needs. Moreover, the liquid nature of deposits creates a high potential for a bank run in case of bad news such as rumours about potential problems of banks, which might spread throughout the entire banking system ${ }^{32}$ and may cause contagion effects.

${ }^{26}$ Positive term transformation refers to the transformation of short-term liabilities to long-term assets, which occurs majorly in banks in the way of the transformation of deposits to credit. Negative term transformation refers to the opposite, for example, when premium income from very long-term life insurance business is invested in shorter-term assets.

${ }^{27}$ See Schierenbeck and Hölscher (1998, p. 27).

${ }^{28}$ However, as stated by Zurich (2007), banks are (to a lower degree) also exposed to non-financial risks, for example, through their credit portfolio that depends on the individual solvency of the creditor and which might be adversely affected by non-financial risks.

${ }^{29}$ See Zurich (2007, p. 8).

${ }^{30}$ See Lehmann and Hofmann (2010, p. 64).

${ }^{31}$ See Geneva Association (2010, p. 29). This is also referred to as the inverted product cycle (see Hofmann and Lehmann, 2009).

${ }^{32}$ An important problem in this context is the asymmetric information, since clients might not be able to judge whether an individual bank failure is due to failure of the individual bank or a failure of the banking system as a whole. Thus, the presence of one bad bank, which becomes insolvent, might spread throughout the entire banking system and thus imply contagion effects (see Zurich, 2007, p. 11). 
In insurance, however, this risk is limited due to the rather long-term funding sources and small incentives for policyholders to withdraw money prematurely, for example due to high surrender costs in life insurance. ${ }^{33}$ In addition, the level of interconnectedness between different undertakings is generally more pronounced in the banking industry than in the insurance industry.

Thus, the risk profiles of banking and insurance differ substantially. While insurance companies are exposed to a significant amount of liability risk resulting from financial and non-financial risks through their insurance business, banks are mostly exposed to asset risks stemming from changes in financial variables as well as liquidity risk. Due to the liquid nature of funding of banks, they are more prone to bank runs, which might spread rapidly throughout the entire banking system. Thus systemic risk is in principle stronger in the banking sector than in the insurance industry.

\section{Characteristics of banking and insurance regulatory schemes}

As discussed above, one of the major differences between the banking and the insurance industry in terms of regulatory purposes is the importance of systemic risks inherent in the respective industry, which is more pronounced in banking due to the danger of the occurrence of bank runs and contagion effects. In line with this, the stated aim of Basel $I I / I I I$ is to reinforce the soundness and stability of the international banking system. Basel II/III hence places special emphasis on the self-regulating mechanisms of a market, where participants are highly dependent on each other and where there is necessarily a high level of systemic risk. Solvency II, in contrast, aims to protect policyholders against the risk of an (isolated) insurer bankruptcy. Systemic risk is thereby not deemed important enough to demand a high level of international regulatory harmonisation. ${ }^{34}$ However, the impact of supervisory decisions on the stability of the financial system and markets are still considered but remain subordinate to the main objective. ${ }^{35}$

Considering the types of risks taken into account, Basel II/III concentrates on risks on the asset side (market, credit) and operational risk. ${ }^{34}$ Consequently, the capital requirements of Pillar 1 are not oriented towards reaching a certain 1-year default probability for the undertaking. Solvency II features a holistic model that combines assets and liabilities and that takes into account all types of risk faced by an insurance company. ${ }^{35}$ Thus insurance capital requirements are based on the economic capital necessary to achieve a certain default probability to ensure payments to policyholders, while the conception behind capital requirements in Basel II/III differs and aims at providing sufficient capital to absorb losses within each of the three risk categories (market, credit and operational risks).

Concerning the approval process, the Basel II/III regulations were brought forward by the international Basel Committee on Banking Supervision ${ }^{36}$ and translated into

\footnotetext{
${ }^{33}$ See Lehmann and Hofmann (2010, p. 65).

${ }^{34}$ See European Commission (2001b).

${ }^{35}$ See Directive 2009/138/EC, p. 3; Directive 2009/138/EC, Articles 27, 28.

${ }^{36}$ This committee provides an international forum for banking regulation. Member states are, among others, China, France, Germany, Japan, Russia, Switzerland, the United Kingdom, and the United States (see http://www.bis.org/bcbs/about.htm).
} 
European law in two Directives (Directive 2006/48/EC and 2006/49/EC). Solvency II, in contrast, is a European initiative and was formalised in the Directive 2009/138/EC in 2009. Both regulatory regimes are adopted by way of the Lamfalussy approach as proposed by "The Committee of Wise Men" in $2001,{ }^{37}$ which intends to simplify and accelerate European legislation by means of a four-level approach. On Level 1, after a consultation process, the European Commission adopts the framework legislation by specifying the core principles and elements of the regulation as well as the extent and general nature of implementing measures. ${ }^{38}$ On Level 2, the implementing measures of the Level 1 Directive are defined in more detail after an open consultation with market participants and end users. ${ }^{39}$ The consultation process is conducted by the European Insurance and Occupational Pensions Authority (EIOPA) and the European Banking Authority (EBA) for the insurance and banking regulation, respectively. The aim of Level 3 is to consistently apply Level 1 and Level 2 legislation in national supervision. This should be carried out through the disclosure of consistent guidelines or periodical peer reviews, for instance. ${ }^{40}$ Finally, on Level 4 , an ongoing supervision by the European Commission is conducted to ensure that Community law is applied consistently in member states. ${ }^{41}$ Thus, the application of the Lamfalussy procedure should lead to a high level of harmonisation and consistency regarding the application of Solvency II and Basel II/III regulations in member states.

\section{Current developments-Basel III}

Basel III has been developed against the background of the financial crisis of 2007/ 2008 and represents an extension of Basel II, which remains in effect. Basel III is planned to be in force after 2013 and its objective is to increase the stability of the international banking sector, mainly by improving the ability of banks to withstand financial and economic stress and by improving the transparency and market discipline by means of detailed disclosure of the capital base. In the following, we focus on five major novelties: the quantity and quality of regulatory capital, the risk coverage under stress, the leverage ratio, additional restrictions for systemically important institutions, and liquidity management.

First, regulators have increased the requirements concerning the quality and quantity of regulatory capital as shown in Figure 1. Here, the definition of tier 1 capital is limited to an emphasis on common shares and retained earnings, that is the common equity capital base ("Core-Tier 1"), which corresponds to approximately three-fourths of the total tier 1 capital. Tier 3 capital is eliminated; under Basel II it could still be used to cover parts of market risk capital requirements. As shown in Figure 1, the common equity capital ratio ("Core-Tier 1 Ratio") increases from

${ }^{37}$ The Lamfalussy procedure was originally proposed for legislation concerning the regulation of the European securities markets in 2001. However, in 2002 the process was adopted for legislation in the whole financial services sector (see European Commission, 2002).

${ }^{38}$ See Committee of Wise Men (2001, p. 22-23).

${ }^{39}$ See Committee of Wise Men (2001, p. 31-32).

${ }^{40}$ See Committee of Wise Men (2001, p. 40-41).

${ }^{41}$ See Committee of Wise Men (2001, p. 43). 


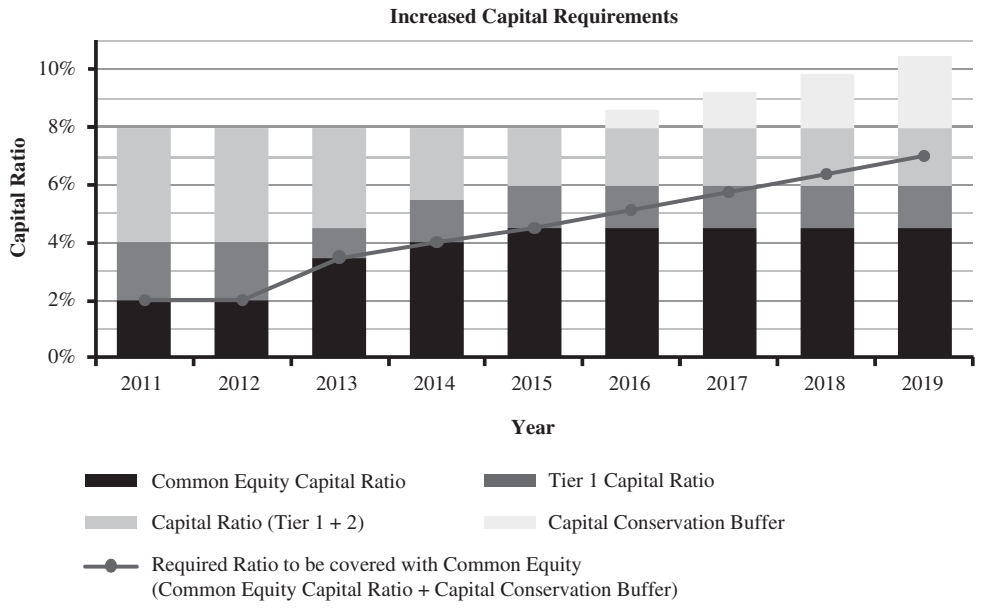

\begin{tabular}{|c|c|c|c|c|c|c|c|c|c|}
\hline & 2011 & 2012 & 2013 & 2014 & 2015 & 2016 & 2017 & 2018 & 2019 \\
\hline $\begin{array}{c}\text { Liquidity } \\
\text { Coverage Ratio } \\
\text { (LCR) }\end{array}$ & $\begin{array}{c}\text { Begin } \\
\text { observation } \\
\text { period }\end{array}$ & & & & $\begin{array}{l}\text { Introduc- } \\
\text { tion mini- } \\
\text { mum } \\
\text { standard }\end{array}$ & & & & \\
\hline $\begin{array}{l}\text { Net Stable } \\
\text { Funding Ratio } \\
\text { (NSFR) }\end{array}$ & & $\begin{array}{l}\text { Begin } \\
\text { observation } \\
\text { period }\end{array}$ & & & & $\begin{array}{l}\text { Introduc- } \\
\text { tion mini- } \\
\text { mum } \\
\text { standard }\end{array}$ & & & \\
\hline
\end{tabular}

Figure 1. Increased capital requirements and timeline for introduction of liquidity ratios under Basel III. (Illustration based on data by $\mathrm{BIS}^{44}$ )

2 per cent of the risk-adjusted assets today to 4.5 per cent in 2015 , the tier 1 capital ratio must be raised from 4 per cent to 6 per cent until 2015, and the capital ratio $($ Tier $1+2)$ is constant at 8 per cent. In addition, a capital conservation buffer of 2.5 per cent is introduced that needs to be covered by common equity capital and is intended to alleviate the pro-cyclical effects of regulation. ${ }^{42}$ This buffer can be reduced during periods of stress and thus serves to absorb losses. When banks approach the minimum capital requirements (MCR), however, supervisory constraints on the earning distribution of the affected bank may be enforced. ${ }^{43}$ Furthermore, a countercyclical buffer of up to 2.5 per cent can be enforced by national supervision in case of excessive credit growth associated with a build-up of system-wide risk. ${ }^{44}$

Second, in order to improve risk coverage, the use of stressed input parameters for the calculation of capital requirements for market risk and credit risk has been introduced. For example, in the case of market risk, banks need to calculate the Value

\footnotetext{
${ }^{42}$ An additional measure in Basel III to lessen pro-cyclicality consists of advocating forward-looking provisioning by promoting an expected loss approach in accounting standards (see BIS, 2010a, pp. 6, 55).

${ }^{43}$ See BIS (2010b, p. 2).

${ }^{44}$ See BIS (2010a, p. 57).
} 
at Risk under the assumption of a 12-month-period of stress. ${ }^{45}$ In addition, while Basel II only takes into account potential losses from own default, under Basel III, potential mark-to-market losses resulting from a rating downgrade of counterparties are considered. Furthermore, Basel III intends to reduce the heavy reliance on external ratings by introducing, for example, the requirement of an internal assessment even if there is an external rating. ${ }^{46}$

Third, since extreme levels of leverage were a main source of losses during the financial crisis, a leverage ratio requirement is introduced to limit leverage in the banking sector. This leverage ratio is not risk-based and will consequently offer some protection against model risk and measurement error. ${ }^{47}$ The fourth measure concerns systemically relevant institutions that belong to the class of "too big to fail". Basel III will likely introduce restrictions, which have yet to be determined and possibly impose additional capital requirements and contingent capital for systemically important institutions. $^{48}$

The fifth issue addressed in Basel III is liquidity management. Here, two ratios are introduced: the Liquidity Coverage Ratio (LCR) and the Net Stable Funding Ratio (NSFR). The time horizon and transition period are also shown in Figure 1. The LCR has a time horizon of 1 month and requires banks to provide sufficient liquidity in the form of unencumbered, high quality liquid assets to withstand a scenario of acute stress. ${ }^{49}$ The NSFR spans a time horizon of 1 year and is supposed to ensure a sustainable maturity structure of assets and liabilities, for example, by limiting reliance on short-term funding. ${ }^{50}$

Thus, while Basel III adds new requirements to compensate weaknesses of Basel II, such as pro-cyclical effects and liquidity issues, the basic set-up and architecture of banking regulation remain intact. Therefore, in the following, for the most part, we refrain from a distinction between Basel II and Basel III and continue to refer to the respective regulatory regime as Basel II/III.

\section{Pillar 1: Quantitative capital requirements}

In this section, the quantitative requirements of both regulatory directives are examined as defined in Pillar 1. The analysis is built upon six selected criteria used by CEA for their comparative study on solvency regimes that allow a consistent comparison of regulatory framework elements. ${ }^{51}$ For the most part, information

\footnotetext{
${ }^{45}$ See BIS (2010a, p. 3).

${ }^{46}$ See BIS (2010a, p. 4).

${ }^{47}$ The leverage ratio is defined as Tier 1 Capital/Exposure, using an accounting measure of exposure. At the time of writing the envisioned minimum leverage ratio is 3 per cent, thus the exposure may not exceed 33 times the amount of equity (see BIS, 2010a, pp. 4; 61).

${ }^{48}$ See BIS (2010a, p. 7).

${ }^{49} L C R=$ (stock of high quality liquid assets) $/$ (total net cash outflows over next 30 calendar days $)>100$ per cent, see BIS (2010a, p. 8; 2010c, p. 3).

${ }^{50}$ NSFR $=$ (available amount of stable funding $) /($ required amount of stable funding $)>100$ per cent, see BIS (2010a, p. 8; 2010c, p. 25).

${ }^{51}$ See CEA (2005, p. 4).
} 
about Solvency II is based on the Directive 2009/138/EC and the fifth quantitative impact study (QIS) of the standard model for deriving solvency capital requirements (SCR) laid out in the "QIS 5 Technical Specifications". While the regulations stated in QIS 5 have not yet been finalised, the standard model will probably be very similar. For Basel II/III, the framework "International Convergence of Capital Measurement and Capital Standards" by BIS ${ }^{3}$ and additional secondary literature are used. In the following, six criteria are compared: (1) risk classes and capital requirements, (2) risk measure and calibration, (3) time perspective, (4) solvency assessment typology, (5) risk aggregation and dependencies, and (6) valuation basis.

\section{Risk classes and capital requirements}

We begin with a comparison of the types of risks taken into account when determining SCR, which vary considerably due to the different risks that banks and insurers are exposed to. In Basel II/III, three risk classes are considered: market risk, credit risk and operational risk. In addition, Basel III has paid special attention to liquidity risk. Solvency II aims at a comprehensive assessment of all quantitatively measurable types of risks to which an insurance company is exposed. Thus, six risk classes with several submodules are included in the calculation of quantitative SCR: underwriting risk for non-life, life and health, market risk, counterparty default risk and operational risk $^{52}$ as shown in Figure 2. Moreover, the latest test of the standard model $^{53}$ accounts for intangibles. ${ }^{54}$

In setting capital requirements, Solvency II adopts a two-level approach. First, the SCR represent the "desired" amount of capital ("target capital"), which can absorb unexpected losses and thus ensures a prescribed low 1-year default probability. The SCR is risk-based and comprises all the risk classes listed above. Second, the MCR is calculated based on a simple combined approach, leading to a corridor between 25 per cent and 45 per cent of the SCR. ${ }^{55}$ The MCR represents the last threshold before the supervisory authority revokes the company's license, if the available capital is not sufficient to cover the MCR. ${ }^{56}$ When breaching the SCR (but not the MCR), the insurance company is granted a period of 6 months, which can be prolonged a further 3 months to re-establish compliance with SCR. ${ }^{57}$ In addition, the free disposal of assets may only be limited in exceptional circumstances. ${ }^{58}$

In contrast, Basel II/III only features one level by requiring a minimum equity capital ratio of 8 per cent (10.5 per cent under the finalised Basel III directives),

\footnotetext{
${ }^{52}$ See Directive 2009/138/EC, Article 101, No. 4.

${ }^{53}$ QIS 5 in 2010.

${ }^{54}$ See QIS 5 (2010, p. 90).

${ }^{55}$ See Directive 2009/138/EC, Article 129, No. 3. Note that Solvency II also imposes an absolute floor to the MCR, the Absolute Minimum Capital Requirements (AMCR), which only depends on the insurance type. For example, for a life insurance company the MCR cannot fall below the AMCR of 3.2 million $€$ (see Directive 2009/138/EC, Article 129, No. 1 d).

${ }^{56}$ See Ayadi (2007, p. 18). After withdrawing a license, the insurer's in-force business is either liquidated or transferred to another insurance company.

${ }^{57}$ See Directive 2009/138/EC, Articles 138; No. 3.

${ }^{58}$ See Directive 2009/138/EC, Articles 138; No. 5.
} 


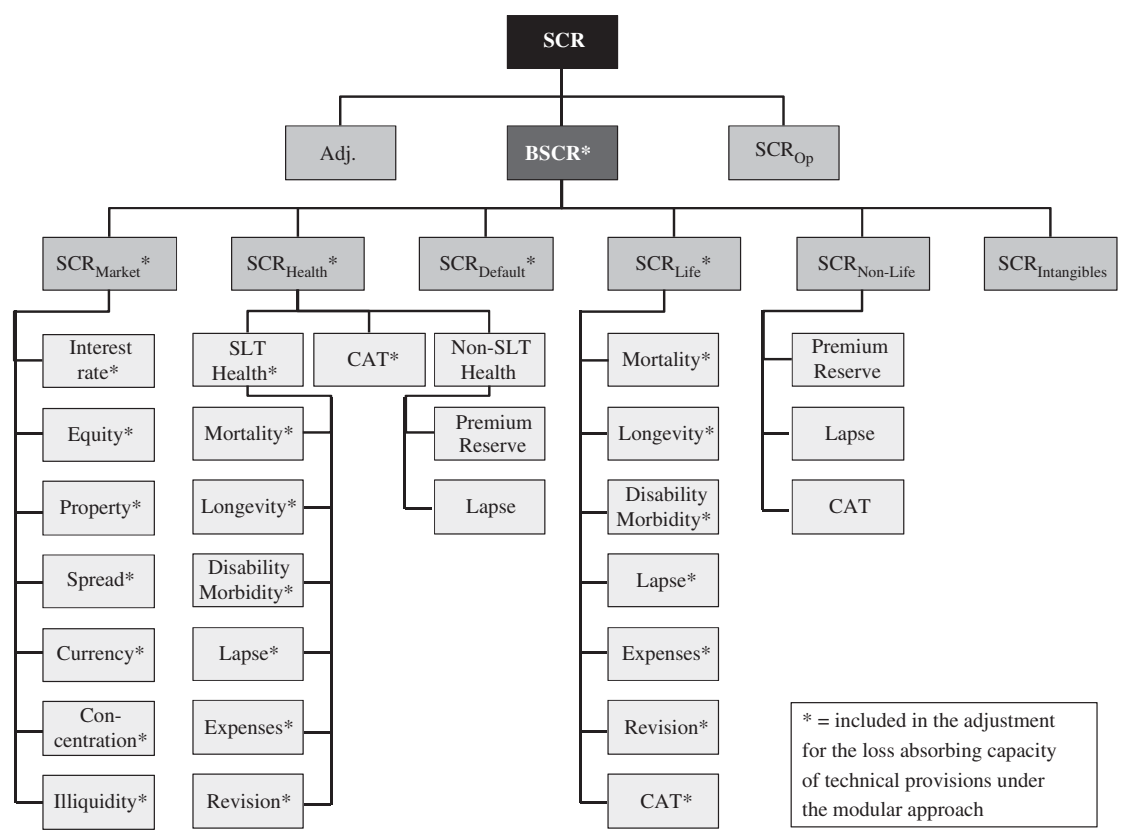

Figure 2. Modules and submodules of the Solvency II standard approach as stated in QIS 5. (See QIS 5, p. 90), BSCR=Basic Solvency Capital Requirements, $\mathrm{Op}=$ Operational Risks, Adj.=Adjustments for the loss absorbing capacity of technical provisions, future discretionary bonus, and deferred taxes.

also called "capital coefficient". However, when taking into account the capital conservation buffer newly introduced in Basel III, banking supervision can be considered as heading towards a two-level approach. The capital requirements must be covered by the companies' available capital. Both schemes classify the capital according to its quality in so-called tiers. As described in detail in the previous section, Basel III has increased the requirements with respect to the quality and quantity of available capital, abandoning tier 3 items. Similarly, Solvency II requires the MCR to be covered with basic own funds, that is, the difference between the market value of assets and liabilities and evaluated in accordance with Solvency II, consisting of at least 50 per cent tier 1 items; regarding SCR, tier 1 must at least constitute one-third and tier 3 items are limited to one-third. ${ }^{59}$ Classification of capital into tiers is thereby based mainly on two criteria. First, funds have to be permanently available to cover losses. Second, funds have to be subordinated, that is, in case of liquidation of the

${ }^{59}$ See Directive 2009/138/EC, Article 98, No. 1-2. However, these values only constitute a lower bound concerning the quality of capital. After the experiences of the financial crisis, regulators become more conservative with respect to capital (see van Hulle, 2011b, p. 8). Thus, in the last quantitative impact study QIS 5, these limits were further increased, requiring that at least 80 per cent of MCR have to be met by tier 1 capital, while tier 3 capital is only allowed to cover a maximum of 15 per cent of SCR (see QIS 5, 2010, p. 304). 
insurance company the redemption of funds is subordinated to other claims. In principle, a position fulfilling both criteria is classified as tier 1, a position fulfilling only the latter as tier 2 , all remaining funds as tier 3 capital. ${ }^{60}$

\section{Risk measure and calibration}

To calculate MCR or SCR, the prescribed risk measure and the required confidence level are of high relevance. Here, both regulatory schemes use in principle the Value at Risk as the relevant risk measure. However, while the Value at Risk is explicitly stated within the directives of Solvency II, ${ }^{61}$ Basel II/III only refers to the Value at Risk in the case of market risk capital requirements. ${ }^{62}$ Regarding credit risk, this formula includes weights that have been adjusted to cover unexpected losses with a certain prescribed probability, that is using a Value at Risk-type risk measure. For operational risk, the risk measure is not specified directly but is required to meet soundness standards comparable to those used for credit risk. ${ }^{63}$ Thus both regulatory schemes generally refer to the risk measure Value at Risk. ${ }^{64}$ Concerning the risk calibration, Basel II/III varies by the risk category: for market risk (Value at Risk), a one-tailed confidence level of 99 per cent has to be achieved; this level is increased to 99.9 per cent for the operational risk advanced approach and in the case of credit risk. ${ }^{65}$ Solvency II, in contrast, requires a fixed confidence level of 99.5 per cent for the insurance company as a whole. ${ }^{66}$ Thus, while the risk calibration in Basel II/III is tied to the single risk categories, that is unexpected losses within each category are considered individually and without aggregation, the Solvency II capital requirements are based on the risk exposure at the company level, thus explicitly taking into account dependencies between risk categories.

\section{Time perspective}

In terms of time perspective and the calculation frequency as well as retrospective or prospective view, both schemes differ considerably. Basel II/III takes a retrospective view: new business is not taken into account. For instance, the basic approach for operational risk uses the gross income during the last 3 years as an indicator for risk exposure. ${ }^{67}$ Furthermore, capital requirements need to be calculated at least twice a year ${ }^{68}$ or even daily if an internal model for market risk is used. ${ }^{62}$ Solvency $I I$ takes a prospective view, taking into account both existing and expected new business within

\footnotetext{
${ }^{60}$ See Directive 2009/138/EC, Articles 93; 94.

${ }^{61}$ See Directive 2009/138/EC, Article 101, No. 3; Article 122, No. 2.

${ }^{62}$ See BIS (2006, p. 195).

${ }^{63}$ See BIS (2006, p. 151).

${ }^{64}$ Note that the Value at Risk is criticised in the scientific literature due to its non-coherence, that is, the lack of sub-additivity (see Artzner et al., 1999). The Swiss Solvency Test, in contrast, uses the coherent Tail Value at Risk (see Federal Office of Private Insurance, 2006).

${ }^{65}$ See BIS (2005, p. 11; 2006, pp. 151; 195).

${ }^{66}$ See Directive 2009/138/EC, Article 101, No. 3.

${ }^{67}$ See BIS (2006, pp. 144-145).

${ }^{68}$ See Directive 2006/48/EC, Article 74, No. 2.
} 
the next 12 months. ${ }^{69}$ Calculation is conducted on a yearly basis, ${ }^{70}$ except in case of a significant change of the risk profile, but solvency must be ensured at all times.

\section{Solvency assessment typology}

An essential aspect of regulatory frameworks is the solvency assessment typology, which refers to rules-based vs. principle-based supervision, simple factor-based, risk factor-based, or scenario-based solvency models as well as the possibility to use individually developed internal models instead of a standard model provided by the regulator. In a rules-based approach, capital requirements are based on stipulated rules, while principle-based capital requirements are calculated based on a risk assessment by the financial institution, thereby following certain prescribed principles. $^{71}$

Thus, the use of internal models - provided in case of both regulatory frameworks to a different extent - is purely principle-based and allows an individual assessment of the company-specific risk situation. If a company cannot develop its own individual internal model, a standard model is provided by the regulator, which in both cases is rather rules- and scenario-based. In particular, the Basel II/III standard approach constitutes a clear rules-based regime. For Solvency II, the standard approach is built on economic principles and for some risk-submodels such as operational risk, capital requirements are calculated based on stipulated rules, which constitutes a deviation from the principle-based nature of Solvency II while other submodules are scenario-based. ${ }^{72}$

Concerning the applicability of internal models to derive capital requirements, considerable differences can be found with respect to the degree of individuality. Depending on the type of risk, Basel II/III offers two to three levels. With respect to market risk, the bank can choose between the standardised measurement method ${ }^{73}$ and the internal approach. ${ }^{74}$ For operational risk, three approaches are available: the basic indicator approach, ${ }^{75}$ the standardised approach and the advanced measurement approach (AMA), which corresponds to the use of an internal model. Regarding credit risk, the standard formula or the internal ratings-based approach (IRBA) can be used. However, both models have heavy restrictions. In particular, only the input parameters can be adjusted to reflect the company-specific situation. This also holds true for the IRBA, where banks may use internal estimates of certain parameters ${ }^{76}$ but are obliged to use the formula stated by the BIS for calculating capital requirement. ${ }^{77}$ Thus, especially the treatment of credit risk is not truly principle-based.

\footnotetext{
${ }^{69}$ See Directive 2009/138/EC, Article 101, No 3.

${ }^{70}$ See Directive 2009/138/EC, Article 102.

${ }^{71}$ See CEA (2005, pp. 10-11).

${ }^{72}$ See CEA (2007, pp. 9-14).

${ }^{73}$ See BIS (2006, p. 166).

${ }^{74}$ See BIS (2006, p. 191).

75 See BIS (2006, p. 144 f.).

${ }^{76}$ See BIS (2005; 2006, p. 52).

${ }^{77}$ See BIS (2006, p. 59).
} 
According to Solvency II, insurance companies are allowed to choose among five levels of sophistication: the development of a full internal model, the use of the standard formula, the standard formula with undertaking-specific parameters, the standard formula that is partly replaced with a partial internal model (e.g. only for certain submodules), or the standard formula with simplifications for smaller companies. $^{78}$ One stated goal of both regulatory schemes is the improvement of internal risk management. Consequently the development of internal models, which first must be certified by supervisory authorities is advocated. ${ }^{79}$

Further distinctions arise in the way capital requirements are calculated in the first place. Simple factor-based models derive capital requirements by multiplying certain accounting positions by a given factor, where the number of factors is generally low. Risk factor-based models are an extension where the factors are applied to a greater number of positions and where factors are generally calibrated to reflect a certain desired confidence level. While these approaches represent static models, capital requirements calculation can also be based on dynamic models, that is, scenario-based or purely principle-based models. ${ }^{80}$ The standard approach in Basel II/III can be classified as a static risk factor-based model for all three risk classes. ${ }^{81}$ While the use of internal models in the case of market and operational risks is in general principlebased, this does not hold for credit risk under Basel II/III. In Solvency II such restrictions are not planned in regard to certified internal models to retain a truly purely principle-based model. ${ }^{82}$ The Solvency II standard formula, in contrast, combines risk factor-based (e.g. for operational risk) ${ }^{83}$ and scenario-based (e.g. market risk, life underwriting risk) approaches. ${ }^{84}$

\section{Risk aggregation and dependencies}

Another important question concerns the consideration of diversification benefits and thus dependencies among risk factors, which can imply substantial reductions in SCR. This aspect is also relevant with respect to the treatment of financial or insurance groups. Here, $\mathrm{CEA}^{23}$ identifies three levels of diversification benefits as illustrated in Figure 3. Level 1 refers to diversification benefits within a specific risk class or a specific business line. Level 2 extends this view to include diversification across risk classes within a specific legal entity (or vice versa); Level 3 takes a holistic perspective and accounts for diversification benefits across all risk classes and across legal entities.

As described in the previous subsections, Basel II/III considers only Level 1 diversification within each of the three risk classes. The capital coefficient and thus the

\footnotetext{
${ }^{78}$ See QIS 5 (2010, p. 93).

${ }^{79}$ See BIS (2006, p. 12), Ayadi (2007, p. 16).

${ }^{80}$ For a definition of these models, see CEA (2005, p. 10).

${ }^{81}$ See BIS (2006, pp. 19-51) for credit risk, BIS (2006, pp. 144-145) for operational risk, and BIS (2006, pp. 166-191) for market risk.

82 See Ayadi (2007, p. 28).

${ }^{83}$ See QIS 5 (2010, pp. 102-104).

${ }^{84}$ See QIS 5 (2010, pp. 109; 147).
} 


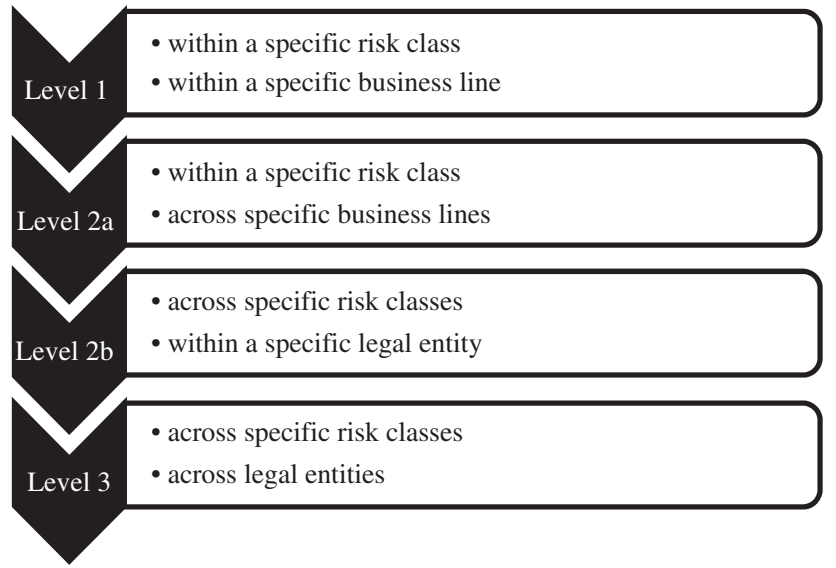

Figure 3. Level of diversification benefits following CEA. ${ }^{23}$

capital requirements are calculated by summing up the capital requirements (CR) resulting from the three risk classes:

$$
\frac{\text { capital }}{\text { sum of credit risk-weighted assets }+12.5 \cdot(\text { CR market risk }+ \text { CR operational risk })} \geqslant 8 \% \text {. }
$$

Thus, any potential diversification effects between the three risk classes are neglected. ${ }^{85}$ Solvency $I I$, in contrast, also accounts for diversification effects among risk classes as reflected in the Basic SCR (BSCR) (see Figure 2), which is calculated using the "square-root formula"

$$
B S C R=\sqrt{\sum_{i, j} \operatorname{Corr}_{i j} \cdot S C R_{i} \cdot S C R_{j}}+S C R_{\text {intangibles }}
$$

for a certain prescribed correlation matrix between risk classes $i, j=$ Market, Health, Default, Life, Non-Life with values $\operatorname{Corr}_{i j}$, where $S C R_{i}$ stands for the SCR of risk class $i{ }^{86}$ Thus, Level 1 and 2 diversification benefits are taken into account. ${ }^{87}$

In the Basel II/III standard approach, concentrations (as the opposite of diversification) are not factored into the calculation of capital requirements. For instance, capital requirements for market risk result from a simple capital charge, independent of potential concentrations. ${ }^{73}$ However, concentration risk is addressed by Pillar 2. In Solvency II, however, risk concentrations are explicitly taken into

\footnotetext{
${ }^{85}$ See BIS (2006, p. 12). In Basel III, the capital conservation buffer and, if applicable, the countercyclical buffer will be added to this ratio.

${ }^{86}$ See QIS 5 (2010, p. 95).

${ }^{87}$ See Directive 2009/138/EC, Article 121, No. 5.
} 
account in a separate submodule within the market risk module ${ }^{88}$ and thus directly increase the SCR. ${ }^{89}$

Regarding the consideration of risk mitigation techniques in reducing SCR, Basel $I I / I I I$ accounts for, for example, collaterals, guarantees, credit risk derivatives and onbalance sheet netting within the credit risk module under certain prescribed principles and requirements. ${ }^{90}$ Within Solvency II, the risk mitigating effect of reinsurance will be acknowledged as will other risk mitigation techniques ${ }^{91}$ such as hedging, insurancelinked securities and swaps. ${ }^{92}$

With respect to group supervision, Solvency II takes into account "the global diversification of risks that exist across all the insurance and reinsurance undertakings", 93 thus in principle implying the consideration of Level 3 diversification benefits. Overall, any diversification or concentration effects as well as potential contagion effects should be properly assessed. ${ }^{94} \mathrm{Basel}$ II/III likewise assesses financial soundness at the fully consolidated group level. ${ }^{95}$ However, since the benefits of diversification are not acknowledged, this procedure is equivalent to adding up the capital requirements of all legal entities. ${ }^{23}$

\section{Valuation basis}

In Basel II/III the valuation basis depends on the risk category. Market risk positions in the trading book have to be valued market consistently, that is, using mark-to-market if possible, and mark-to-model, otherwise. ${ }^{96}$ For credit risk, the exposure is determined as the balance sheet value and thus constitutes an accounting value. ${ }^{97}$ These valuation bases give rise to two main pitfalls in the Basel II/ III regime. First, the lack of a common valuation basis circumvents the application of a consistent risk metric and second, valuation in Pillar 1 is not conducted using a forward-looking approach. ${ }^{98}$ Within Solvency II, assets and liabilities other than technical provisions, are valued according to the fair value criteria using mark-to-market or mark-to-model, if readily available market prices are not available. The valuation should thereby be based on the underlying principles as stated in the IFRS system only if the IFRS produce an economic value in line with the fair value criteria. ${ }^{99}$ The value of technical provisions should reflect the price the liability could be traded for on a market, that is be valued following the market consistency criteria and is consequently based on a best estimate plus an additional

\footnotetext{
${ }^{88}$ See Directive 2009/138/EC, Article 105, No. 5 (f).

${ }^{89}$ See QIS 5 (2010, p. 127).

${ }^{90}$ See BIS (2006, p. 32).

${ }^{91}$ See Directive 2009/138/EC, Article 101, No. 5.

${ }^{92}$ See, for example, CEA (2007); Swiss Re (2007).

${ }^{93}$ See Directive 2009/138/EC, p. 10.

${ }^{94}$ See van Hulle (2011a).

${ }^{95}$ See Directive 2006/49/EC, p. 4.

96 See BIS (2006, pp. 160-162).

${ }^{97}$ See Directive 2006/48/EC, Article 78, No. 1.

${ }^{98}$ This is only addressed in the internal risk management process in Pillar 2.

${ }^{99}$ See QIS 5 (2010, pp. 6-7).
} 
risk margin ${ }^{100}$ reflecting the cost of capital beyond the best estimate necessary to support the business. ${ }^{101}$ Hence, Solvency II aims at a completely economic balance sheet and thus provides a common valuation basis. In addition, the economic balance sheet and the valuation of technical provisions are forward-looking, while the elements of Pillar 1 in Basel II/III are not. As a further difference, it can be stated that while Solvency II takes a total balance sheet approach that includes assets and liabilities, ${ }^{102}$ Basel II/III does not.

\section{Summary}

Table 1 summarises the main similarities and differences between the two regimes.

\section{Pillar 2: Qualitative aspects of risk management}

This section deals with the qualitative requirements with respect to risk management and the supervisory review process described in Pillar 2. Both regulatory schemes are analysed based on six criteria: (1) principles, aims and scope of supervision, (2) considered risks, (3) internal risk management process, (4) general governance requirements and organisational structure, (5) additional capital requirements, and (6) powers of supervision. For Solvency II, the Directive 2009/138/EC and partly the advice on the implementing measures by CEIOPS ${ }^{103}$ are used as relevant sources. However, as stated by CEIOPS, ${ }^{103}$ the Level 1 text (i.e. the Directive) contains a relatively high level of detail (especially compared to the corresponding Level 1 text for Basel II), such that we refer as much as possible to the legally binding and finalised Level 1 text. For Basel II/III, the Level 1 text contains a rather limited amount of information and details. Therefore, we mainly refer to the Level 2 "Guidelines on the Application" by CEBS. ${ }^{104}$

\section{Principles, aims and scope of supervision}

The principles underlying supervision are similar for both regulatory regimes: the proportionality principle has to be applied in both cases and the approach to supervision should be risk-based. ${ }^{105}$ However, one important difference lies in the prospective view taken by supervision within the Solvency II regime, which is not explicitly required for Basel II/III, in particular in regard to Pillar 1 . However, in Pillar 2, some elements are prospective and forward-looking such as the Internal Capital Adequacy Assessment Process (ICAAP). ${ }^{106}$

\footnotetext{
${ }^{100}$ See QIS 5 (2010, p. 20).

101 See QIS 5 (2010, p. 55).

102 See Directive 2009/138/EC, p. 5.

103 CEIOPS (2009a).

104 CEBS (2006).

105 See CEBS (2006, p. 26) for Basel II/III and Directive 2009/138/EC, Article 29, No. 1 for Solvency II.

${ }^{106}$ See CEBS (2006, p. 27). In addition, the supervisory review process in Pillar 2 should identify potential problems and thus incorporates certain prospective elements.
} 
Table 1 Differences and similarities of Basel II/III and Solvency II with respect to Pillar 1

\begin{tabular}{|c|c|c|}
\hline Criteria & Basel II/III & Solvency II \\
\hline $\begin{array}{l}\text { Risk classes } \\
\text { and capital } \\
\text { requirements }\end{array}$ & $\begin{array}{l}\text { Mainly asset risks (market and credit } \\
\text { risk) and operational risk; special } \\
\text { focus on liquidity risk in Basel III } \\
\text { - Only MCR, moving towards two- } \\
\text { level approach in Basel III by way of } \\
\text { introducing a countercyclical buffer }\end{array}$ & $\begin{array}{l}\text { - Aims at a comprehensive } \\
\text { approach taking into account all } \\
\text { major risk, that is underwriting } \\
\text { risk, market risk, default risk, } \\
\text { operational risk } \\
\text { Two-level approach - SCR and } \\
\text { MCR }\end{array}$ \\
\hline $\begin{array}{l}\text { (2) Risk } \\
\text { measure and } \\
\text { calibration }\end{array}$ & $\begin{array}{l}\text { - Value at Risk-type measure } \\
\text { - Capital requirements specified for } \\
\text { each risk class separately } \\
\text { - Varying confidence level for different } \\
\text { risk classes, that is } 99 \% \text { for market } \\
\text { risk and } 99.9 \% \text { for credit and } \\
\text { operational risk } \\
\text { Capital requirements intended to } \\
\text { cover unexpected losses within each } \\
\text { risk category with a given probability }\end{array}$ & $\begin{array}{l}\text { - Value at Risk } \\
\text { - Capital requirements based on } \\
\text { exposure at company level } \\
\text { Aims at confidence level of } 99.5 \% \\
\text { for the insurance company as a } \\
\text { whole } \\
\text { - Capital requirements intended to } \\
\text { ensure a given 1-year solvency } \\
\text { probability for insurance company } \\
\text { as a whole }\end{array}$ \\
\hline (3) Time perspective & $\begin{array}{l}\text { - Retrospective } \\
\text { More frequent recalculation, that is, } \\
\text { twice a year or daily in case of an } \\
\text { internal model for market risk }\end{array}$ & $\begin{array}{l}\text { - Prospective } \\
\text { - Recalculation in principle only } \\
\text { once a year, but solvency must be } \\
\text { ensured at all times }\end{array}$ \\
\hline $\begin{array}{l}\text { (4) Solvency } \\
\text { assessment } \\
\text { typology }\end{array}$ & $\begin{array}{l}\text { - Choice between two to three levels of } \\
\text { sophistication, for example standard } \\
\text { formula or IRBA for credit risk } \\
\text { - Restrictions concerning the use of } \\
\text { internal models for credit risk } \\
\text { - Only risk factor-based approach in } \\
\text { the standard model }\end{array}$ & $\begin{array}{l}\text { Choice between five levels of } \\
\text { sophistication - from full internal } \\
\text { model to standard formula with } \\
\text { simplifications } \\
\text { No restrictions concerning } \\
\text { internal models } \\
\text { - Scenario-based and risk factor- } \\
\text { based approaches in the standard } \\
\text { model }\end{array}$ \\
\hline $\begin{array}{l}\text { (5) Risk aggregation } \\
\text { and dependencies }\end{array}$ & $\begin{array}{l}\text { - Only Level } 1 \text { diversification benefits } \\
\text { are acknowledged }\end{array}$ & $\begin{array}{l}\text { - All levels of diversification } \\
\text { benefits are acknowledged }\end{array}$ \\
\hline (6) Valuation basis & $\begin{array}{l}\text { - Market-based (market risk) and } \\
\text { accounting based (credit risk) }\end{array}$ & - Purely economic balance sheet \\
\hline
\end{tabular}

In contrast to the principles, the stated main objectives of Pillar 2 of the regulatory schemes differ. Basel $I I / I I I$ explicitly states the objective of strengthening and encouraging efficient and advanced risk management in order to ensure capital adequacy. ${ }^{107}$ In Solvency II, on the contrary, there is no separate goal defined for 
Table 2 Scope of supervision for banking and insurance

Basel II/III Solvency II

- Revision and evaluation of strategies, processes and reporting procedures (see Articles 30; 36)

- Assessment of internal governance, incl. ICAAP (see CEBS, 2006, pp. 26-27)

- Assessment of all material risks (see CEBS, 2006, p. 26)

- Compliance with capital requirements (see CEBS, 2006, p. 28)

- Assessment of potential deficiencies in control and risk management framework as well as identification of existing and potential key risks (see CEBS, 2006, p. 27)
- Assessment of qualitative requirements relating to the system of governance, incl. ORSA (see Article 36, No. 1)

- Assessment of all risks faced by undertaking (see Article 36, No. 1)

- State of solvency and compliance with capital requirements (see Article 30; 36, No. 1)

- Assessment of methods and practices of undertaking for identifying potential events and changes in economic condition that may threaten solvency (see Article 36, No. 4)

- Establishment of technical provisions, assets and eligible own funds (see Article 30)

Pillar 2 in the Level 1 and 2 texts. However, the higher ranking goal of the regulatory regime is repeated and remains valid, that is, the protection of policyholders and beneficiaries ${ }^{108}$ where the impact of supervisory decisions on the stability of the financial system should be accounted for as a subordinated goal especially during times of extraordinary stress. ${ }^{109}$

While the scope of supervision is almost identical as shown in Table 2, two areas are not addressed in Basel II/III in this context (but are discussed in regard to the internal risk management process): high level issues like strategies, processes and reporting procedures, as well as valuation issues concerning technical provisions, assets and own funds, which are considered in Solvency II.

\section{Risks taken into account}

In principle, all material risks should be taken into account in Basel II/III as well as in Solvency II. For Basel II/III, this includes but is not limited to credit risk, operational risk, market risk - including illiquidity and concentration risks - interest rate risk in the banking book, liquidity risk and other risks such as reputational and strategic risks. Where risks cannot be measured precisely, they should be estimated based on a reliable process. ${ }^{110}$ Thus, by considering liquidity risk, the interactions between assets

108 See Directive 2009/138/EC, Article 27.

${ }^{109}$ See Directive 2009/138/EC, Article 28.

${ }^{110}$ See BIS (2006, pp. 206-208). 
and liabilities are partly taken into account within Pillar 2, while Pillar 1 concentrates on risks on the asset side. Solvency II prescribes a risk management process that should at least involve all risks connected with underwriting and reserving, assetliability management, investments (in particular derivatives), liquidity and concentration, operational, as well as reinsurance and other risk-mitigating techniques. ${ }^{111}$ Furthermore, CEIOPS ${ }^{103}$ proposes to take into account credit risk, strategic and reputational risk. ${ }^{112}$ Thus, when comparing these risk categories, the interaction between assets and liabilities seems to receive much more attention in the insurance sector by explicitly including asset-liability management in addition to liquidity risk in risk management.

\section{Internal risk management process}

Another central aspect of both schemes is the internal risk management process. Basel II/III and Solvency II detail the introduction and implementation of an internal process for risk management. This process is referred to as the ICAAP for banks, which must be risk-based, comprehensive and forward-looking. ${ }^{113}$ Thus, the potential limitations of Pillar 1, such as the retrospective view are addressed in Pillar 2. For insurance undertakings, the ORSA process is implemented. Both processes need to form an integral part of management and decision-making. However, while in Solvency II, the emphasis is rather directed towards strategic decisions and issues, ${ }^{114}$ the function of the Basel II/III ICAAP ranges from support in everyday decisions (e.g. individual credit decision) to higher level strategic ones ${ }^{115}$ and is thus emphasised in Basel II/III.

The outcome of both processes is a capital requirement, which however, does not determine legal capital requirements. ${ }^{116}$ Still, Basel II/III states that deviations between the capital requirements resulting from the ICAAP and the regulatory capital requirements need to be explained to the supervisory authority. ${ }^{117}$ Insurance undertakings are obliged to explain any deviations in their risk profile to the one assumed in the standard formula ${ }^{118}$ since these deviations might lead to diverging capital requirements and consequently to a misleading SCR when applying the standard formula. Thus an important function of the internal risk management process for banks and insurance companies is the support for determining legal capital requirements, which are, for example, deduced using a one-size-fits-all standard formula with company-specific information.

\footnotetext{
111 See Directive 2009/138/EC, Article 44, No. 2, Munich Re (2009).

112 See CEIOPS (2009a, pp. 40-42).

113 See CEBS (2006, pp. 22-23).

114 See Directive 2009/138/EC, Article 45, No. 4.

115 See CEBS (2006, p. 21).

116 See CEBS (2006, p. 24); Directive 2009/138/EC, Article 45, No. 7.

117 See CEBS (2006, p. 24).

${ }^{118}$ See Directive 2009/138/EC, Article 45, No. 1.
} 


\section{General governance requirements and organisational structure}

The principles concerning general government requirements and the organisational structure are very similar in both regulatory schemes. Regarding the government requirements, both prescribe a clear and transparent organisation with adequate reporting lines as well as a clear allocation (and segregation) of responsibilities. ${ }^{19}$ However, Solvency II emphasises the importance of written policies ${ }^{120}$ for risk management, internal control, internal audit and, where relevant, outsourcing. ${ }^{121}$ Basel II/III, in contrast, requires the existence of written policies only at the level of the management body. ${ }^{122}$ A further innovation within Solvency $I I$ is an explicit requirement concerning the qualification of the management body running the company. These persons have to be "fit", that is, possess the necessary professional qualifications and "proper", in other words, to be of "good repute and integrity". ${ }^{123}$ Furthermore, the development of contingency plans is demanded for insurance as well as for banks. ${ }^{124}$

Concerning the organisation, the risk management function has to be effective and well integrated into the organisational structure ${ }^{125}$ and serve as a central function, ${ }^{122}$ thus being given special importance in both schemes. The internal control function in banks includes the three functions risk control, compliance and internal audit, ${ }^{126}$ whereas in Solvency II, internal control (including compliance) and internal audit functions are listed as separate functions. ${ }^{127}$ In addition, both functions need to be objective and independent from operational functions. ${ }^{128}$ For insurance undertakings, an actuarial function is the fourth mandatory function (in addition to risk management, internal control and internal audit).

\section{Additional capital requirements}

Concerning additional capital in excess of the Pillar 1 capital requirements, a fundamental difference between the two supervisory regimes exists. While according to Basel II/III banks are expected to operate above the capital requirements stated in Pillar 1, that is, to hold additional buffer capital for bank-specific uncertainties, ${ }^{129}$ this is not explicitly planned in Solvency II. The stated reasons for this capital buffer for banks are, among others, fluctuations in economic conditions leading to changes in the capital ratio, costs associated with raising additional capital, the severe consequences of falling below a capital ratio of 8 per cent, and the presence of potential risks not

\footnotetext{
119 See CEBS (2006, p. 11), Directive 2009/138/EC, Article 41.

${ }^{120}$ See CEIOPS (2009a, p. 3).

${ }^{121}$ See Directive 2009/138/EC, Article 41, No. 3.

122 See CEBS (2006, p. 12).

123 See Directive 2009/138/EC, Article 42, No. 1.

${ }^{124}$ See CEBS (2006, p. 23), Directive 2009/138/EC, Article 41, No. 4.

125 See Directive 2009/138/EC, Article 44, No. 1.

126 See CEBS (2006, p. 16).

127 See Directive 2009/138/EC, Articles 46; 47.

${ }^{128}$ See CEBS (2006, p. 16), Directive 2009/138/EC, Article 47.

${ }^{129}$ See BIS (2006, p. 211).
} 
taken into account in Pillar 1. ${ }^{129}$ As described in the previous section, Solvency II in contrast uses a two-level approach to derive capital requirements in Pillar 1, where SCR constitutes the desired target capital and MCR represent the minimum capital requirements. ${ }^{130}$ Thus, a breach of SCR does not have as severe consequences as a breach of the capital requirements in Basel II/III. However, as the market consistent valuation approach adds volatility, insurance companies will likely also be forced to operate with higher own funds to counterbalance this effect. Thus, while Pillar 1 of Solvency II sets two levels of capital (MCR and SCR), only one level is set in Basel II, supplemented with the countercyclical buffer in Basel III, which is then complemented by the described requirements in Pillar 2, such that banks are consequently also generally obliged to hold capital in excess of the MCR.

\section{Powers of supervision}

Both regulatory schemes emphasise the possibility for early intervention on the part of supervisory authorities. Within the Solvency II framework, supervisory authorities have the power to take "preventive and corrective measures", ${ }^{131}$ and Basel II/III prescribes intervention at an early stage to prevent banks from falling below the capital requirements. ${ }^{132}$ The explicit measures of the supervisory authority are addressed in more detail in Basel II/III. In particular, Article 136, No. 1 of Directive 2006/48/EC specifies the following five measures: increasing MCR, requiring internal governance to comply with stated rules, application of a specific provisioning policy or treatment of assets in terms of own funds requirements, restriction or limitation of business, operations or network of credit institution, and reduction of risk. ${ }^{133}$ Solvency II, in contrast, only very generally states that any financial or administrative measures may be taken if deemed necessary. ${ }^{134}$ In addition, a capital add-on may be imposed after the supervisory review process in exceptional and clearly defined circumstances. ${ }^{135}$

\section{Summary}

Table 3 summarises the main similarities and differences between the two regimes with respect to Pillar 2.

\section{Pillar 3: Disclosure requirements}

Pillar 3 addresses disclosure requirements. While in Basel II/III, only public disclosure is discussed, Solvency II addresses public disclosure as well as the harmonisation of supervisory reporting. ${ }^{136}$ Since supervisory reporting is not addressed in Basel II/III,

\footnotetext{
${ }^{130}$ See Barnier (2011, p. 2).

131 See Directive 2009/138/EC, Article 34, No. 1.

132 See BIS (2006, p. 212).

133 See Directive 2006/48/EC, Article 136, No. 1.

${ }^{134}$ See Directive 2009/138/EC, Article 34, No. 2.

135 See Directive 2009/138/EC, Article 37.

${ }^{136}$ See European Commission (2006, p. 7).
} 
Table 3 Differences and similarities of Basel II/III and Solvency II with respect to Pillar 2

\begin{tabular}{|c|c|}
\hline Criteria & Basel II/III \\
\hline $\begin{array}{l}\text { (1) Principles, aims } \\
\text { and scope of } \\
\text { supervision }\end{array}$ & $\begin{array}{l}\text { - Proportionality principle } \\
\text { - } \text { Obis-based supervision } \\
\text { advancement of efficient risk } \\
\text { management; capture all risks that } \\
\text { are not captured within Pillar } 1\end{array}$ \\
\hline
\end{tabular}

Solvency II

(2) Risks taken into account

(3) Internal risk management process

(4) General governance requirements and organisational structure

(5) Additional capital requirements

(6) Powers of supervision
- All material risks

- Including, but not limited to: credit risk, operational risk, market risk - including illiquidity and concentration risks - interest rate risk in the banking book, liquidity risk, other risks such as reputational and strategic risks

- Integral part of risk management and decision-making

- Function: support of everyday as well as strategic decisions and issues; complement capital requirements deduced in Pillar 1 by company specific information

- Outcome: capital requirement

- Clear and transparent organisation accompanied by the respective reporting lines; clear allocation of duties

- Written policies only at the level of the management body

- Mandatory functions: effective and well integrated risk management, internal control (including risk control, compliance and internal audit)
- Proportionality principle

- Risk-based supervision

- Objective: no separate goals defined; higher ranking goal remains valid, Differences and similarities of Basel II/III and protection of policyholder; subordinated goal: stability of the financial system

- All material risks

- Including, but not limited to: underwriting and reserving, assetliability management, investments (in particular derivatives), liquidity and concentration, operational, reinsurance and other risk-mitigating techniques

- Integral part of risk management and decision-making

- Function: support of strategic decisions and issues; complement capital requirements deduced in Pillar 1 by company-specific information

- Outcome: capital requirement

- Clear and transparent organisation accompanied by the respective reporting lines; clear allocation of duties

- Emphasis on written policies for risk management, internal control, internal audit and outsourcing

- Mandatory functions: effective and well integrated risk management, internal control, internal audit and actuarial function

- Government body has to be "fit" and "proper"

- Not envisioned by supervisory authority above capital requirement stated in Pillar 1

- Possibility to intervene at an early stage - emphasis on prevention
- Possibility to intervene at an early stage - emphasis on prevention 
we concentrate on public disclosure requirements. As in the previous sections, we will hereby refer to the Level 1 and Level 2 texts of the respective regulation. In both regulatory regimes, mandatory quantitative reporting templates are defined on Level 3 of the Lamfalussy process, which might require a higher level of detail concerning the information to be disclosed than the previously mentioned regulations stated in Level 1 and 2 texts. However, for Solvency II, these have not been finalised yet, so that we do not take them into account for either regime to avoid inconsistencies.

\section{Aim and application}

The aim of Pillar 3 for both regulatory schemes is the promotion of market discipline and market mechanisms ${ }^{137}$ by providing market participants with all material information. Materiality is thereby defined identically in both regulatory regimes in line with the definition given by the International Financial Reporting Standards (IAS-IFRS) as any information the omission of which would change or influence economic decisions. ${ }^{138}$ In Basel II/III, public disclosure requirements apply at the consolidated top level and, consequently, individual entities are not obliged to fulfil the criteria laid out in the following subsection. ${ }^{139}$ Under Solvency II, however, disclosure requirements apply both at the level of the individual undertaking and at the group level. ${ }^{140}$

\section{Content of report to the public}

Table 4 shows the content of the public disclosure report for banks and insurance undertakings separated into four subcategories. Concerning own funds, the composition as well as the amount and quality of own funds has to be publicly disclosed. Basel $I I / I I I$ prescribes publication of any restrictions on capital transfers within the group, since public disclosure requirements apply only at the top consolidated level. In Solvency II, this is not deemed necessary since publication of all information also has to be conducted on the individual company level.

Even though both banks and insurance companies are obliged to disclose capital requirements, the level of detail varies in the Level 1 and Level 2 texts. While Solvency II demands the publication of the SCR and the MCR for the undertaking as a whole, Basel II/III prescribes the disclosure of capital requirements for the separate risk types, that is credit risk, market risk and operational risk, in addition to the total capital ratio and the tier 1 capital ratio. Public disclosure demands concerning qualitative requirements for risk management are more detailed in Solvency II. For example, the report should contain a description of the business and performance as well as all major differences between the assumptions underlying the standard formula for calculating SCR and the institution's individual risk profile. Both regulatory schemes

\footnotetext{
${ }^{137}$ See BIS (2006, p. 226), CEIOPS (2009b, p. 12).

${ }^{138}$ See BIS (2006, p. 227), CEIOPS (2009b, p. 23).

${ }^{139}$ An exception to this rule constitutes the requirement to disclose the total as well as the tier 1 capital ratio for all significant bank subsidiaries (see BIS, 2006, p. 229).

${ }^{140}$ See CEIOPS (2009b, p. 26).
} 
Table 4 Content of public disclosure report

\begin{tabular}{|c|c|c|c|c|}
\hline Criteria & Base & el II & Solv & vency $I I$ \\
\hline \multirow{3}{*}{ Own funds } & $\bullet$ & Restriction on capital transfer within group & - & \\
\hline & $\bullet$ & Description of main features of capital & $\bullet$ & Structure of own funds \\
\hline & & $\begin{array}{l}\text { Amount of tier } 1 \text { capital (separated into } 8 \\
\text { specific subcategories) as well as amount of } \\
\text { tier } 2 \text { and } 3 \text { capital }\end{array}$ & $\bullet$ & $\begin{array}{l}\text { Amount and quality of } \\
\text { own funds }\end{array}$ \\
\hline \multirow[t]{3}{*}{ Capital requirements } & $\bullet$ & $\begin{array}{l}\text { Total and tier } 1 \text { capital ratio calculated on a } \\
\text { consolidated basis and for significant } \\
\text { subsidiaries }\end{array}$ & & $\begin{array}{l}\text { Size of SCR and MCR } \\
\text { (incl. if applicable capital } \\
\text { add-on) }\end{array}$ \\
\hline & $\bullet$ & Capital requirements for separate risk types & - & \\
\hline & - & & & $\begin{array}{l}\text { Additionally any non- } \\
\text { compliance with MCR } \\
\text { and/or SCR }\end{array}$ \\
\hline \multirow[t]{3}{*}{$\begin{array}{l}\text { Information } \\
\text { concerning } \\
\text { qualitative } \\
\text { requirements in } \\
\text { Pillar II }\end{array}$} & - & & & $\begin{array}{l}\text { Description of business and } \\
\text { performance }\end{array}$ \\
\hline & & $\begin{array}{l}\text { Discussion of approach used for assessing } \\
\text { capital adequacy } \\
\text { Description of objectives and policies for risk } \\
\text { management; for all risk types separately }\end{array}$ & & $\begin{array}{l}\text { Description of system of } \\
\text { governance and assessment } \\
\text { of its adequacy in light of } \\
\text { the risk profile }\end{array}$ \\
\hline & - & & & $\begin{array}{l}\text { Main differences between } \\
\text { assumptions of standard } \\
\text { formula and risk profile of } \\
\text { undertaking }\end{array}$ \\
\hline $\begin{array}{l}\text { Additional } \\
\text { information for } \\
\text { separate risk } \\
\text { categories }^{\text {a }}\end{array}$ & • & $\begin{array}{l}\text { Most detailed disclosure requirements for } \\
\text { credit risk including, for example, definition } \\
\text { of past due and impaired loans, risk } \\
\text { management policies concerning credit risk, } \\
\text { gross risk exposure, distribution of exposures } \\
\text { (geographic, counterparty, industry, residual } \\
\text { contractual maturity, etc.), amount of } \\
\text { impaired loans } \\
\text { For market risk capital requirements: } \\
\text { separately for four subcategories } \\
\text { For operational risk methods: for assessing } \\
\text { operational risk the bank is qualified to use }\end{array}$ & & $\begin{array}{l}\text { Risk profile (see CEIOPS, } \\
2009 \mathrm{~b}, \text { p. } 31 \text { ), that is, } \\
\text { information concerning } \\
\text { risk exposure, } \\
\text { concentration, mitigation, } \\
\text { and sensitivity; separately } \\
\text { for all risk types }\end{array}$ \\
\hline
\end{tabular}

${ }^{\mathrm{a}}$ We concentrate on basic requirements for banks and insurance undertakings using the standard approach. In case of the use of an internal model, additional disclosure requirements must be fulfilled.

Source: BIS (2006, pp. 229-241), Directive 2009/138/EC, Article 51. 
further demand publication of quantitative and qualitative information for separate risk categories. Some examples are shown in Table 4.

\section{Summary of main differences and similarities}

Although Basel II/III and Solvency II appear very similar because of the same three-pillar structure, the comparative assessment of both regulatory frameworks revealed several major discrepancies in the specifications of the three pillars, particularly with respect to the quantitative requirements laid out in Pillar 1. This can in part be attributed to the different characteristics of the industries, and to the different goals of supervision. In the banking industry, the focus on systemic risk and system stability is more pronounced, particularly because of the highly liquid nature of funding, which might lead to contagion effects spreading throughout the entire financial system, endangering even sound banking institutions, as well as the high interconnectedness, enabling negative shocks to spread faster throughout the entire banking system. This results in a stronger emphasis on promoting the stability of the financial system in Basel II/III, while the main objective of Solvency II is the protection of the individual policyholders, with stability of the financial system and the consideration of pro-cyclical effects rather representing side goals. ${ }^{141}$

In contrast to Solvency II, Basel II/III does not aim at achieving a safety level for the whole company, but instead focuses on the three individual risk classes on the asset side: market risk, credit risk and operational risk. Solvency II requires a holistic perspective and, based on a total (economic) balance sheet approach, accounts for assets and liabilities in order to achieve a 1-year company solvency probability of at least 99.5 per cent. This implies that while risk calibration in Basel II/III is tied to the three single risk categories by considering unexpected losses within each category individually, the Solvency II capital requirements explicitly account for dependencies and diversification benefits among risk categories. In general, insurance companies are exposed to considerably more risks on the liability side due to the vertical risk transformation and the resulting insurance risks, while the liability side of banks mainly consists of deposits with a fixed value. Yet, in combination with the asset side, liquidity risk arises, which is addressed in Pillar 2 of Basel II and further strengthened in Basel III. ${ }^{142}$ Overall, supervisory authorities expect banks to exceed MCR, so the capital requirements calculated in Pillar 1 do not actually constitute the final constraint that has to be satisfied. In Solvency II, the two-level approach will probably enable insurance companies to operate closer to the SCR. However, the added volatility, coming along with market consistent valuation, might partly counteract this effect.

Another important difference between the two schemes is that Basel II/III is not purely principles-based, in particular with respect to deriving capital requirements for credit risk, which even in the case of an internal model has to comply with strong restrictions. In Solvency II, in contrast, the use of internal models is purely

\footnotetext{
${ }^{141}$ See Directive 2009/138/EC, Articles 27, 28; Wandt and Sehrbrock (2011).

${ }^{142}$ Additional restrictions concerning liquidity of e-money institutions are stated in Directive 2000/46/EC.
} 
principles-based and planned to be encouraged to integrate regulatory requirements into internal risk management processes. However, crucial success factors in this respect are the resources and capacity of the certifying regulatory authority, their willingness to accept internal models, as well as the ability to avoid an excessive bureaucracy implying high impediments for insurers.

Hence, Solvency II can be considered as a further development of Basel II in some aspects, in particular with respect to Pillar 1 and its holistic approach, which, however, comes along with a considerably higher degree of complexity. Especially the latest QIS in 2010, QIS 5, introduced a high level of complexity when testing the fifth version of the standard model for calculating capital requirements according to Pillar 1. While the instructions of the last QIS for Basel II filled about 50 pages, the Solvency II technical specifications of the standard model have more than 300 . The higher degree of complexity may in some cases even prevent a more frequent calculation (even though listed stock insurers typically need to publish at least quarterly) at acceptable costs as compared to the case of the simpler and easier to implement rules-based model of Basel II/III, which, however, offers less flexibility to adjust the model to the company-specific risk situation and is mainly based on book values, thus not providing a market-based or economic viewpoint. There is thus a trade-off between the benefits of a total balance sheet approach along with its deeper insight into a firm's risk situation and the associated costs, which has not been empirically analysed to date.

However, Solvency II still offers a wide range of flexible solutions, for example, by means of using institution-specific input parameters for the standard formula, which allows an adaption to the individual institution. In particular, two to three levels of freedom in deriving capital requirements are given in Basel II/III, while Solvency II offers up to five, ranging from a complete internal model to the use of a simplified version of the standard model. Yet at the current stage, more transparency is needed with respect to the origin of the input parameters used in the standard model and the presumed type of company, for which a safety level of 99.5 per cent is actually achieved when implementing the standard model as, for example, laid out in QIS 5. For instance, with respect to premium and reserving risk in non-life, Hampel and Pfeifer ${ }^{143}$ show that the calculation of the standard formula seems to implicitly assume a loss ratio of 100 per cent, which is not stated in the technical specifications and cannot be considered as prudent for all branches. Hence, companies with a lower loss ratio are advised to insert their own loss ratio to reduce capital requirements. This example illustrates the importance of providing transparency for insurers with respect to the background of the input parameters stated in the technical specifications to enable them to adjust their model accordingly.

The Solvency II standard model also exhibits several other problems in its details. For instance, the liquidity premium added to the risk-free interest rate provided by the regulators may imply undesirable incentives with respect to firms' asset-liability management, among other effects, as insurers with an actually insufficient assetliability management are able to reduce the value of their liabilities in times of financial

${ }^{143}$ Hampel and Pfeifer (2011). 
distress and may thus appear similarly stable to firms with an adequate risk management. ${ }^{144}$ Furthermore, government bonds of European Economic Area (EEA)-member states are currently not subject to capital requirements, independent of their credit quality also implying that corporate bonds with longer contract terms have a disadvantage in this respect. This induces possible adverse interaction effects between the two regulatory regimes in insurance and banking, especially with respect to financing issues, as for example, banks are envisioned to issue more bonds with longer contract terms following Basel III, which in Solvency II however, are subject to higher capital requirements as compared to EEA-government bonds.

In Pillar 2, the function of the ICAAP in supporting operative daily business decisions is emphasised more heavily in Basel II/III as compared to the ORSA in Solvency II. Requirements concerning general government requirements and the organisational structure are otherwise very similar; this also holds true for the reporting requirements in Pillar 3.

\section{Conclusion}

In conclusion, the comparative assessment of Solvency II and Basel II/III allowed the detection of similarities and differences as well as benefits and shortcomings of both regimes, which provides an opportunity to rectify their drawbacks. With respect to Basel II/III, this especially concerns the lack of a common valuation basis in Pillar 1, which prevents a consistent risk metric, as well as the use of forward-looking valuation approaches. Furthermore, the financial crisis emphasised that liquidity risk arising from an asset-liability mismatch can be substantial. Thus, while Basel II mostly concentrates on risks on the assets side, a stronger emphasis on the relationship between assets and liabilities - along the lines of the total balance sheet approach of Solvency $I I$ - and the resulting liquidity risk management could potentially be advantageous. In addition, the principles-based nature and the use of internal models as in Solvency II might also be profitably adapted to Basel II/III, especially as a truly principles-based regulation is the best way to ensure sufficient flexibility to adopt regulation to the constantly changing business environment as laid out in Schiro, ${ }^{145}$ and since internal models might harbour further advantages as also pointed out by Liebwein. $^{146}$

For insurance companies, the introduction of the integrated Solvency II approach will overall certainly improve the risk perspective of insurance companies and their ability to achieve a comprehensive and adequate picture of the risk situation. However, as described before, while the standard model of Solvency II provides an integrated perspective on an insurer's risk situation, there is a trade-off due to its complexity, which in turn introduces the potential for model risk due to numerous assumptions regarding processes and dependencies. This should be dealt with by means of, for example, sensitivity analyses to avoid wrong incentives. In addition,

\footnotetext{
144 See Gründl (2011).

145 Schiro (2006).

146 Liebwein (2006).
} 
several details of the standard model require reconsideration as laid out in the previous section.

While Solvency II might be less prone to pro-cyclical effects than Basel II/III, since it is calibrated to long-term observations and because its principles-based nature makes it more flexible, ${ }^{147}$ the possibility of pro-cyclical effects, especially concerning the investment behaviour and its potential impact on financial markets, including prices of stocks as well as corporate and government bonds, should be subject to further research. This also concerns the effectiveness of the current measures against pro-cyclicality planned in the standard model. ${ }^{148}$ Furthermore, as pointed out by Doff $^{12}$ and Ashby, ${ }^{149}$ a more balanced approach between Pillar 1 and Pillars 2 and 3 in Solvency $I I$ appears reasonable. Here Basel II/III could in some aspects serve as an example, where regulations of Pillar 1 are supplemented by specific regulations in Pillar 2. This might as well be useful for lowering the level of complexity currently envisioned in QIS 5.

Caution is also advised with respect to regulatory bureaucracy and impediments that may prevent a true principles-based approach and induce a trend towards a rules-based regime or one that actually lowers transparency. In this context, the proportionality principle is essential, implying that risk management, capital requirements and reporting requirements should correspond to a firm's risk situation. In addition, a high degree of transparency is needed with respect to assumptions that constitute the basis for capital requirement and in regard to the way in which regulators actually deal with companies that do not achieve a safety level of 99.5 per cent (but instead, e.g. 97.5 per cent), which should be clearly addressed and communicated. Finally, besides studies on possible pro-cyclical effects, cost-benefit analyses are needed to gain deeper insight with respect to the consequences of the new European regulatory framework for insurance companies, along with a consideration of possible adverse interaction effects between the two regulatory regimes.

\section{Acknowledgements}

The authors would like to thank two anonymous referees for valuable comments and suggestions on an earlier version of this paper.

\section{References}

Altman, E.I. and Sabato, G. (2005) 'Effects of the New Basel capital accord on bank capital requirements for SMEs', Journal of Financial Services Research 28(1-3): 15-42.

Angelini, P., Clerc, L., Cúrdia, V., Gambacorta, L., Gerali, A., Locarno, A., Motto, R., Roeger, W., Van den Heuvel, S. and Vlček, J. (2011) Basel III: Long-term impact on economic performance and fluctuations, BIS Working Paper No. 338.

\footnotetext{
${ }^{147}$ See Geneva Association (2010, p. 109).

${ }^{148}$ Heid (2007), for example, finds that capital buffers as introduced in Basel III can be very efficient in reducing the impact of the volatility of capital requirements, which can substantially vary during an economic cycle and thus lessen pro-cyclical effects.

149 Ashby (2011).
} 
Artzner, P., Delbaen, F., Eber, J.-M. and Heath, D. (1999) 'Coherent measures of risk', Mathematical Finance 9(3): 203-228.

Ashby, S. (2011) 'Risk management and the global banking crisis: Lessons for insurance solvency regulation', The Geneva Papers on Risk and Insurance-Issues and Practice 36(3): 330-347.

Ayadi, R. (2007) 'Solvency II: A revolution for regulating European insurance and re-insurance companies', Journal of Insurance Regulation 26(1): 11-35.

Ayuso, J., Perez, D. and Saurina, J. (2004) 'Are capital buffers pro-cyclical?: Evidence from Spanish panel data', Journal of Financial Intermediation 13(2): 249-264.

Bank for International Settlements (BIS) (2005) 'An explanatory note on the Basel II IRB risk weight functions', http://www.bis.org/, accessed 12 April 2011.

Bank for International Settlements (BIS) (2006) 'International convergence of capital measurement and capital standards-A revised framework-Comprehensive version', http://www.bis.org/, accessed 23 December 2010.

Bank for International Settlements (BIS) (2010a) 'Basel III: A global regulatory framework for more resilient banks and banking systems', http://www.bis.org/, accessed 16 February 2011.

Bank for International Settlements (BIS) (2010b) 'Press release - Group of governors and heads of supervision announces higher global minimum capital standards', http://www.bis.org/, accessed 16 February 2011.

Bank for International Settlements (BIS) (2010c) 'Basel III: International framework for liqudity risk measurement, standards and monitoring', http://www.bis.org/, accessed 28 September 2011.

Bank for International Settlements (BIS) (2010d) 'An assessment of the long-term economic impact of stronger capital and liquidity requirements', http://www.bis.org/, accessed 28 September 2011.

Barnier, M. (2011) 'Letter from Michel Barnier, commissioner for internal market and services to representatives of the CEA, CRO Forum, CFO Forum and PEIF', http://ec.europa.eu/internal_market/ insurance/solvency/index_en.htm, accessed 29 September 2011.

Barth, J.R., Caprio, G. and Levine, R. (2004) 'Bank regulation and supervision: What works best?' Journal of Financial Intermediation 13(2): 205-248.

Benford, J. and Nier, E. (2007) Monitoring cyclicality of Basel II/III capital requirements, Financial Stability Paper No. 3 - December 2007, Bank of England.

Blundell-Wignall, A. and Atkinson, P. (2010) 'Thinking beyond Basel III: Necessary solutions for capital and liquidity', OECD Journal: Financial Market Trends, 1: 1-23.

Comité Européen des Assurances (CEA) (2005) 'Solvency assessment models compared', http://www .naic.org/, accessed 14 December 2010.

Comité Européen des Assurances (CEA) (2007) 'Solvency II-Understanding the process', http://www .cea.eu/, accessed 15 December 2010.

Committee of European Banking Supervisors (CEBS) (2006) 'Guidelines on the application of the supervisory review process under pillar 2', http://www.eba.europa.eu/, accessed 21 December 2010.

Committee of European Insurance and Occupational Pensions Supervisors (CEIOPS) (2009a) 'CEIOPS' advice for Level 2 implementing measures on Solvency II: System of governance', https://eiopa.europa.eu/, accessed 15 December 2010.

Committee of European Insurance and Occupational Pensions Supervisors (CEIOPS) (2009b) 'CEIOPS' advice for Level 2 implementing measures on Solvency II: Supervisory reporting and public disclosure requirements', https://eiopa.europa.eu/, accessed 15 December 2010.

Committee of Wise Men (2001) 'Final report of the committee of wise men on the regulation of European securities markets', http://ec.europa.eu/, accessed 26 September 2011.

Cummins, D., Harrington, S. and Niehaus, G. (1994) 'An economic overview of risk-based capital requirements for the property-liability industry', Journal of Insurance Regulation 11(4): 427-447.

Cummins, D. and Phillips, R.D. (2009) 'Capital adequacy and insurance risk-based capital systems', Journal of Insurance Regulation 28(1): 25-72.

Dacorogna, M. and Keller, P. (2010) Principle-based solvency: A comparison between Solvency II and the Swiss Solvency Test, SCOR Papers, no. 8.

Decamps, J.-P., Rochet, J.-C. and Roger, B. (2004) 'The three pillars of Basel II: Optimizing the mix', Journal of Financial Intermediation 13(2): 132-155.

Doff, R. (2008) 'A critical analysis of the Solvency II proposals', The Geneva Papers on Risk and InsuranceIssues and Practice 33(2): 193-206. 
Duverne, D. and Le Douit, J. (2009) 'IFRS Phase II and Solvency II: Key issues, current debates', The Geneva Papers on Risk and Insurance-Issues and Practice 34(1): 47-55.

Elderfield, M. (2009) 'Solvency II: Setting the pace for regulatory change', The Geneva Papers on Risk and Insurance-Issues and Practice 34(1): 35-41.

Eling, M., Gatzert, N. and Schmeiser, H. (2008) 'The Swiss Solvency Test and its market implications', Geneva Papers on Risk and Insurance - Issues and Practice 33(3): 418-439.

Eling, M. and Holzmüller, I. (2008) 'An overview and comparison of risk-based capital standards', Journal of Insurance Regulation 26(4): 31-60.

Eling, M., Klein, R.W. and Schmit, J.T. (2009) Insurance regulation in the United States and the European Union - A comparison, independent policy report, The Independent Institute.

Eling, M., Schmeiser, H. and Schmit, J.T. (2007) 'The Solvency II process: Overview and critical analysis', Risk Management and Insurance Review 10(1): 69-85.

European Commission (2001a) 'Solvency II: Presentation of the proposed work', MARKT/2027/01, http://ec.europa.eu/internal_market/insurance/index_en.htm, accessed 21 December 2010.

European Commission (2001-b) 'Banking rules: relevance for the insurance sector?', MARKT/2056/01, http://ec.europa.eu/internal_market/insurance/index_en.htm, accessed 14 December 2010.

European Commission (2002) 'Financial markets: Commission welcomes parliament's agreement on Lamfalussy proposals for reform', http://ec.europa.eu/internal_market/securities/lamfalussy/index_en.htm, accessed 26 September 2010.

European Commission (2003) 'Design of a future prudential supervisory system in the EU-Recommendations by the commission services', MARKT/2509/03 http://ec.europa.eu/internal_market/insurance/index_en.htm, accessed 21 December 2010.

European Commission (2006) 'Amended framework for consultation on Solvency II', MARKT/2515/06, http://ec.europa.eu/internalmarket/insurance/index_en.htm, accessed 21 December 2010.

Federal Office of Private Insurance (2006) 'Technical document on the Swiss Solvency Test', http:// www.finma.ch/, accessed 21 January 2011.

Flamée, M. and Windels, P. (2009) 'Restructuring financial sector supervision: Creating a level playing field', The Geneva Papers on Risk and Insurance - Issues and Practice 34(1): 9-23.

Geneva Association (2010) 'Systemic risk in insurance - An analysis of insurance and financial stability', Special Report of The Geneva Association Systemic Risk Working Group http://www.genevaassociation .org/, accessed 23 December 2010.

Gründl, H. (2011) 'Anmerkungen zu Solvency II', Presentation, Frankfurt am Main, 14 June 2011, GoetheUniversity Frankfurt.

Hampel, M. and Pfeifer, D. (2011) 'Eigenmittelanforderung unter Solvency II-Betrachtung der Standardformel für das Prämien- und Reserverisiko im versicherungstechnischen Nichtlebenbereich', Presentation at the Annual Meeting of the German Insurance Science Association.

Heid, F. (2007) 'The cyclical effects of the Basel II capital requirements', Journal of Banking \& Finance 31(12): 3885-3900.

Herring, R. (2005) 'Implementing Basel II: Is the game worth the candle?' Financial Markets, Institutions \& Instruments 14(5): 267-287.

Hofmann, D.M. and Lehmann, A.P. (2009) 'Dedicated insurers are not a systemic risk-An assessment after the first year of the global credit crisis', Insurance Economics 59: 1-3.

Holzmüller, I. (2009) 'The United States RBC standards, Solvency II and the Swiss Solvency Test: A comparative assessment', The Geneva Papers on Risk and Insurance-Issues and Practice 34(1): 56-77.

Lehmann, A.P. and Hofmann, D.M. (2010) 'Lessons learned from the financial crisis for risk management: Contrasting developments in insurance and banking', The Geneva Papers on Risk and Insurance-Issues and Practice 35(1): 63-78.

Liebwein, P. (2006) 'Risk models for capital adequacy: Applications in the context of Solvency II and beyond', The Geneva Papers on Risk and Insurance - Issues and Practice 31(3): 528-550.

Munich Re (2009) 'Reinsurance's qualitative contribution to value added within the framework of Pillar 2 of Solvency II', Solvency consulting knowledge series, http://www.munichre.com/, accessed 15 December 2010.

QIS 5 (2010) 'Technical specifications, internal market and services DG, financial institutions, insurance and pensions', http://ec.europa.eu/internal_market/insurance/index_en.htm, accessed 15 December 2010.

Schierenbeck, H. and Hölscher, R. (1998) Bankassurance, 4th edn, Stuttgart: Schäfer-Poeschel Verlag. 
Schiro, J.J. (2006) 'External forces impacting the insurance industry: Threats from regulation', The Geneva Papers on Risk and Insurance - Issues and Practice 31(1): 25-30.

Steffen, T. (2008) 'Solvency II and the work of CEIOPS', The Geneva Papers on Risk and Insurance-Issues and Practice 33(1): 60-65.

Swiss Re (2007) 'Solvency II framework', Presentation at IUMI 2007 Conference, Copenhagen.

Van Hulle, K. (2011a) 'Solvency II könnte ein Modell für die Welt werden', Versicherungswirtschaft 66(1): 14-19.

Van Hulle, K. (2011b) 'Solvency II: State of play and perspectives', Zeitschrift für die gesamte Versicherungswissenschaft 100(2): 177-192.

Vaughan, T.M. (2009) 'The implications of Solvency II for U.S. insurance regulation', Policy Brief, Networks Financial Institute at Indiana State University.

Von Bomhard, N. (2010) 'The advantages of a global solvency standard', The Geneva Papers on Risk and Insurance-Issues and Practice 35(1): 79-91.

Wandt, M. and Sehrbrock, D. (2011) 'Regelungsziele der Solvency II-Rahmenrichtlinie', Zeitschrift für die gesamte Versicherungswissenschaft 100(2): 193-206.

Warrier, S.R. (2007) 'Lessons learned', Best's Review, February 2007.

Zurich (2007) 'Regulation and intervention in the insurance industry - Fundamental issues', $w w w$ .zurich.com/, accessed 22 December 2010.

\section{About the Authors}

Nadine Gatzert studied Mathematics and Economics at the University of Ulm, Germany and at the University of Southern California in Los Angeles, U.S., majoring in Mathematical Finance and Actuarial Science. She received her Doctoral degree in 2007 and her Postdoctoral qualification in 2009 from the University of St. Gallen, Switzerland. Since 2009, she holds the Chair for Insurance Economics and Risk Management at the Friedrich-Alexander-University of Erlangen-Nürnberg, Germany. Her main research interests include enterprise risk management, financial guarantees, alternative risk transfer, and regulation in the financial services industry.

Hannah Wesker is a $\mathrm{PhD}$ candidate at the Friedrich-Alexander-University of ErlangenNürnberg, Chair for Insurance Economics and Risk Management. She holds a Diploma in Business Administration from the University of Erlangen-Nürnberg. Her research interests include risk management in life insurance, valuation of life insurance liabilities, and regulation in the financial services industry. 